\title{
HALHÚS-FOGYASZTÁSI SZOKÁSOK VIZSGÁLATA EGY SZEGEDI KÖZÉPISKOLA, VALAMINT EGY EGYETEMI KAR HALLGATÓINAK KÖRÉBEN
}

\author{
Zsótér Brigitta - Ács Eszter
}

\begin{abstract}
Absztrakt: Környezetünknek vagy saját döntésünknek köszönhetỏen próbálunk odafigyelni az egészséges táplálkozásra (Szakály et al., 2014). Figyelünk a termékek összetételére, és megpróbálunk kizárni bizonyos élelmiszereket (Kontor et al., 2016). Szakértők szerint az egészséges táplálkozás egyik elengedhetetlen feitétele a halhús fogyasztása, ennek megfelelöen hetente minimum egyszer halat kellene fogyasztanunk (Szakály, 2011). Kutatásunk tárgya a halfogyasztási szokások felmérése volt egy szegedi középiskola diákjai és egy egyetemi kar hallgatói körében. Célul tủztük ki annak felmérését, hogy milyen okok állnak a halfogyasztás alacsony mértéke mögött. Továbbá vizsgálni kívántuk, hogy a halhús mellett mely húsfajták fogyasztása a leggyakoribb az általunk megkérdezettek körében. A táplálkozási attitüdök és a húsfogyasztás összefüggéseiröl szól egy tavalyi tanulmány melyböl kiderül, hogy számos tényező befolyásolja étkezéseinket (Nábrádi et al., 2017). Kutatásunk során kiderült, hogy a hal ára döntő szerepet játszik a fogyasztásban.
\end{abstract}

Abstract: Due to our environment or to our own decision, we try to pay attention to healthy nutrition (Szakály et al., 2014). We pay attention to the composition of the products and try to exclude certain foods (Kontor et al., 2016). Experts state that fish consumption is one of the indispensable conditions of a healthy diet, so we should consume fish at least once per week (Szakály, 2011). The focus of our research was to survey the habits of fish consumption among the students of a secondary school and of a university faculty in Szeged. Our goal was to uncover the causes behind the low rate of fish consumption. Furthermore, we aimed to investigate that, beside fish, which types of meats are the most commonly consumed among the interviewed. A study of last year shows the connections between nutrition attitudes and meat consumption, from which it turns out that several factors influence our meals (Nábrádi et al., 2017). During our research it was revealed that the price of fish plays a decisive role in consumption.

Kulcsszavak: hal, fogyasztás, Z-próba, szezonalitás

Keywords: fish, consumption, Z-test, seasonality

\section{Bevezetés}

Témaválasztásunkat indokolja, hogy rendkívül fontosnak tartjuk az egészséges életmódra való törekvést. Számos élelmiszerfogyasztási kockázat ismert, azonban jelen vannak az ezeket orvosoló kockázatkezelési alternatívák is. (Lehota, 2006). Szervezetünk számára nélkülözhetetlen tápanyagforrások, vitaminok (pl.: A; B1; $\mathrm{B} 2$; D vitamin), ásványi anyagok és különböző telítetlen és többszörösen telítetlen zsírsavak (pl.: Omega-3 zsírsav) jelentős része biztosítható azáltal, hogy nagyobb mértékben rendszeresítjük a halat a táplálkozásunkban (Szakály, 2017). A halfogyasztás szerves része az egészséges életvitelnek (Kiss et al., 2016). További fogyasztói szokás vizsgálatokról olvashatunk Hampel György (2016) tanulmányában is. Mindemellett megjegyeznénk, hogy az élelmiszer biztonságról (Gál, 2008), ezen belül a hökezelésről (Fabulya-Hampel, 2016), a minőségirányításról (Tisca et al., 2015) és a minőségmenedzsmentröl nem szabad megfeledkeznünk (Scalera et al., 2012). 
Kutatásunk átfogó célja a halfogyasztás élettani szerepének és egy gimnázium, valamint egy egyetemi kar hallgatói körében a halfogyasztási helyzet bemutatása volt. Az általunk végzett kutatás segítségével az alábbi hipotéziseket kívánjuk vizsgálni:

1. Többen vannak azon válaszadók, akik nem fogyasztanak halat, mint azok, akiknek, ha ritkán is, de táplálkozásukban megjelennek különböző halak, vagy ezekből előállított készítmények.

A halfogyasztók a halhús mellett leggyakrabban baromfi- és sertéshúst fogyasztanak.

Magas fokú szezonalitás figyelhető meg a halfogyasztás vonatkozásában pl. a karácsonyi ünnepek időszakában több halat fogyasztanak a megkérdezettek. $\mathrm{Az}$ alábbi diagram is szemlélteti, hogy annak ellenére, hogy a halhús finom és egészséges, nem képezi részét mindennapi étrendünknek (KISS, 2017).

\section{1. ábra: Diagram halfogyasztás gyakoriságáról}

A halfogyasztás gyakorisága a megkérdezettek válaszai alapján $(n=429)$

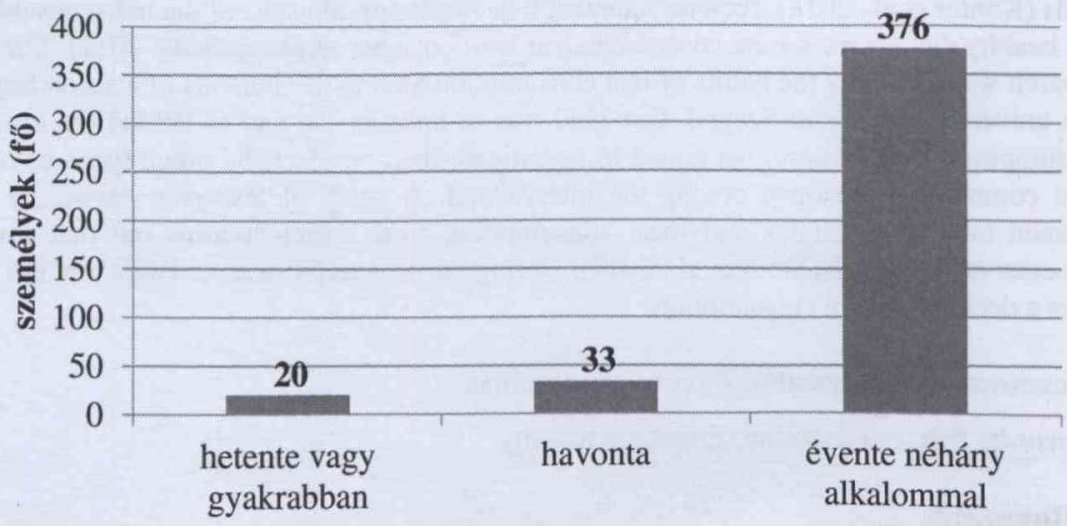

gyakoriság

Forrás: saját készítésü ábra a kiértékelt kérdöívek alapján.

\section{Anyag és módszer}

Primer kutatásunk alapját egy általunk összeállított kérdőív adta, amelyet a Szegedi Radnóti Miklós Kísérleti Gimnázium középiskolás diákjai, és a Szegedi Tudományegyetem Juhász Gyula Pedagógusképző Kar hallgatói töltöttek ki. Összesen 429 kérdőív került kitöltésre. 2017-ben március és április hónapokban zajlott a kitöltetés. Kérdöívünk 15 kérdést tartalmazott, melyböl 10 kérdés vonatkozott a kérdöívkitöltő halfogyasztási szokásaira és az ezzel kapcsolatos véleményére, 5 kérdés pedig demográfiai adatokat tárta fel. A legtöbb kérdés zárt formában került papírra. A kérdőív megszerkesztését követően próbakitöltetést végeztünk 2017 februárjának végén. Ez lehetőséget biztosított arra, hogy kiderüljön, hogy a kérdéssor logikai felépítése megfelelő, a kérdésformák ideálisak-e (Lehota, 
2001). A kitöltők száma összesen 435 volt, azonban 6 kérdőív nem minösült értékelhetőnek, így az értékelés során 429 elemes mintát vizsgáltunk. A kutatásba bevont személyeket tájékoztattuk jelen munka céljáról, továbbá, hogy a közölt adatokat a személyiségi jogok maradéktalan tiszteletben tartása mellett kezeljük (Malhotra, 2008). A kérdőíveket a PSPP statisztikai rendszer segítségével értékeltük $\mathrm{ki}$, amely rendszer helyettesíti a szabadalmaztatott Statistical Package for the Social Sciences, SPSS nevü programot (Sajtos-Mitev, 2007). Azért éltünk ezzel a lehetöséggel, hogy hatékonyan és gyorsan tudjuk feldolgozni az adatokat. (HuzsvaiVincze, 2012). Az elemzésekkel kapott eredmények összevetéséhez az PSPP kiválóan alkalmas (Jánosa, 2007). A hipotézisvizsgálatot $\mathrm{Z}$ próba segítségével végeztük el, melynek lényege, hogy állítunk valamit és a vizsgálat során kialakult minta alapján megnézzük, hogy adott valószínủség (95\%) mellett a teljes sokaságra teljesül-e.

\section{Eredmények és értékelésük}

A bevezető fejezetben három hipotézist fogalmaztunk meg, melyek értékelésére későbbi, személyes kutatásunk adatai és azok kiértékelése adta meg a választ. Tekintettel a terjedelmi korlátokra a kutatási eredmények részletezését $\mathrm{e}$ tanulmányban nem közöljük, a dolgozat e részét a hipotézisvizsgálat végeredményének ismertetésére korlátozzuk.

1. hipotézis: Többen vannak azok, akik nem fogyasztanak halat, mint azok, akiknek, ha ritkán is, de táplálkozásukban megjelennek különbözö halak, vagy ezekböl előállított készítmények. Azaz a vizsgált sokaságban a halat fogyasztók aránya több mint (vagy legalább) $50 \%$.

$\mathrm{n}=429$ (a minta nagysága)

Halat nem fogyasztók: 30 fö

k=30 (nullhipotézisnek megfelelöen válaszolók száma)

Halat fogyasztók: 399 fö

$\mathrm{P}=0,5000$ (a feltételezett érték)

Összes válaszadó: 429 fő

$\mathrm{p}=\mathrm{k} / \mathrm{n}=0,0699$ (a mintából számított érték)

Z-próba:

$\mathrm{H}_{0}: \mathrm{p} \geq 0,5 \leftarrow$ Nullhipotézis.

$\mathrm{H}_{\mathrm{A}}: \mathrm{p}<0,5 \leftarrow$ Alternatív hipotézis, a relációjel alapján bal oldali próba. $\downarrow$

(Bal oldali próbánál elfogadjuk a nullhipotézist, ha z-érték > kritikus érték.)

Szignifikancia szint: $\alpha=0,05$ (hibavalószínüség)

Az elfogadási tartomány (kritikus érték): $Z_{0,05}=-1,645$

Z-próba értéke: $\quad Z=\frac{k-n P}{\sqrt{n P(1-P)}}$ vagy $Z=\frac{P-P}{\sqrt{\frac{P(1-P)}{n}}}=-17,815$ 
Statisztikai következtetés: A Z-próba értéke kisebb a kritikus értéknél $\rightarrow$ a nullhipotézist elutasítjuk 5\%-os szignifikancia szinten, illetve 95\%-os valószínúség mellett.

Szakmai következtetés: A vizsgált sokaságban többen vannak a halfogyasztók a halat nem fogyasztóknál.

2. hipotézis: A halfogyasztók a halhús mellett leggyakrabban baromfi- és sertéshúst fogyasztanak. Azaz, a hal mellett egyéb húst fogyasztók között a baromfihúst és sertéshúst fogyasztók aránya több mint (vagy legalább) $50 \%$.

$\mathrm{n}=379$ (a minta nagysága)

Baromfi és sertéshús: 379 fö

k=379 (nullhipotézisnek megfelelően válaszolók száma)

Egyéb húsfélék: 0 fö

$\mathrm{P}=0,5000$ (a feltételezett érték)

Összes válaszadó: 379 fő

$\mathrm{p}=\mathrm{k} / \mathrm{n}=1,000$ (a mintából számított érték)

Z-próba:

$\mathrm{H}_{0}: \mathrm{p} \geq 0,5 \leftarrow$ Nullhipotézis.

$\mathrm{H}_{\mathrm{A}}: \mathrm{p}<0,5 \leftarrow$ Alternatív hipotézis, a relációjel alapján bal oldali próba.

$\downarrow$

(Bal oldali próbánál elfogadjuk a nullhipotézist, ha z-érték > kritikus érték.)

Szignifikancia szint: $\alpha=0,05$ (hibavalószínüség)

$A z$ elfogadási tartomány (kritikus érték): $Z_{0,05}=-1,645$

$$
\text { Z-próba értéke: } \quad Z=\frac{k-n P}{\sqrt{n P(1-P)}} \text { vagy } Z=\frac{p-P}{\sqrt{\frac{P(1-P)}{n}}}=19,468
$$

Statisztikai következtetés: A Z-próba értéke nagyobb a kritikus értéknél $\rightarrow$ a nullhipotézist elfogadjuk 5\%-os szignifikancia szinten, illetve 95\%-os valószínüség mellett.

Szakmai következtetés: A vizsgált sokaságban a hal mellett egyéb húst fogyasztók között többségben vannak a baromfi-és sertéshúst fogyasztók.

3. hipotézis: Magas fokú szezonalitás figyelhető meg a halfogyasztás vonatkozásában pl. a karácsonyi ünnepek időszakában több halat fogyasztanak a megkérdezettek. Azaz, a vizsgált sokaság legalább 50\%-ának véleménye szerint a halfogyasztásban szezonalitás figyelhető meg a karácsonyi időszakban. $\mathrm{n}=429$ (a minta nagysága)

A fenti állítással egyetért: 382 fő k=382 (nullhipotézisnek megfelelően válaszolók)

A fenti állítással nem ért egyet: 47 fő

$\mathrm{P}=0,5000$ (a feltételezett érték)

Összes válaszadó: 429 fö

$\mathrm{p}=\mathrm{k} / \mathrm{n}=0,8904$ (a mintából számított érték) 
Z-próba:

$\mathrm{H}_{0}: \mathrm{p} \geq 0,5 \leftarrow$ Nullhipotézis.

$\mathrm{H}_{\mathrm{A}}: \mathrm{p}<0,5 \quad \leftarrow \quad$ Alternatív hipotézis, a relációjel alapján bal oldali próba. $\downarrow$

(Bal oldali próbánál elfogadjuk a nullhipotézist, ha z-érték > kritikus érték.)

Szignifikancia szint: $\alpha=0,05$ (hibavalószínüség)

$A z$ elfogadási tartomány (kritikus érték): $Z_{0,05}=-1,645$

Z-próba értéke: $\quad Z=\frac{k-n P}{\sqrt{n P(1-P)}}$ vagy $Z=\frac{p-P}{\sqrt{\frac{P(1-P)}{n}}}=16,174$

Statisztikai következtetés: A Z-próba értéke nagyobb a kritikus értéknél $\rightarrow$ a nullhipotézist elfogadjuk 5\%-os szignifikancia szinten, illetve 95\%-os valószínüség mellett.

Szakmai következtetés: A vizsgált sokaság véleményének többsége szerint halfogyasztásban szezonalitás figyelhetỏ meg a karácsonyi időszakban.

\section{Következtetések, összegzés, záró megjegyzések, záró gondolatok}

A fenti 2017 tavaszán végzett kutatás során alapvető problémaként fogalmazódott meg a téma vonatkozásában a hal ára, legyen szó élö, vagy feldolgozott halról.

A kutatás lezárását követően, még a 2017-es évben javaslatként fogalmazódott meg a hal és halászati termékek árának csökkentése. A 2018. januárjában 5\%-ra csökkentett áfa a fogyasztási célú halakra vonatkozóan elömozdíthatja a halfogyasztást, hiszen elérhetöbbé válik a halhús, így várhatóan növekedni fog iránta a kereslet. A fentiek a téma vizsgálatának folytatására adnak lehetőséget.

Ezen túl javasoljuk az egészséges halhús több helyen való árusítását, hiszen a felmérés alapján lenne igény a friss halra az év több szakaszában is, nem csak az ünnepekkor. Véleményünk szerint fellendítené a hazai halfogyasztást, ha az emberek több helyen hozzájutnának a kiváló minőségú és fontos, hogy friss halhoz (Soós, 2017). Javasoljuk továbbá a halhús szervezetre gyakorolt jótékony hatásának még markánsabb módon való reklámozását, a halat még nem fogyasztókban való egyértelmü tudatosítását. Hiszen sokan nincsenek tisztában azzal, hogy milyen mértékben támogatja a halhúsban fellelhető számos vitamin, ásványi anyag és telítetlen zsírsav az emberi szervezetet. Véleményünk szerint, minél többen tudnak ezekröl a fontos információkról, annál többen fognak fogyasztani. Fontosnak tartjuk, hogy a tudatosítást több területen végezzék. Úgy gondoljuk, az iskolákban is fel kellene hívni a figyelmet arra, hogy egészségünk megörzésének ügyében a halfogyasztás rendkívüli szerepet tölt be. Amennyiben a diák/hallgató már az iskolai évei alatt találkozik az egészséges életmódra való törekvés fontosságával, és annak eszközeivel (pl.: halfogyasztás), úgy felnött korában, önálló élete során nagyobb valószínủséggel fog tudatosan tenni ezért. Megoldást jelenthet az emberek figyelmének felhívása arra, hogy mennyi ízletes étel készíthetö a halból, amely étel azáltal, hogy halból készül egészséges is lesz. Nem terheli meg szervezetünket, ugyanakkor jóizủen fogyaszthatja a család bármely tagja. Ezzel kapcsolatban halhúst 
felhasználó receptek, azok elkészítését demonstráló videók terjesztését javasoljuk az interneten vagy akár a közösségi oldalakon is. Összegezve a témával kapcsolatos információkat, belátható, hogy a halfogyasztás egészséges és ezzel párhuzamosan szükséges is.

\section{Köszönetnyilvánítás}

Támogatónk az Emberi Erőforrások Minisztériuma, az Emberi Erőforrás Támogatáskezelő és a Nemzeti Tehetség Program (NTP-HHTDK-017-0004).

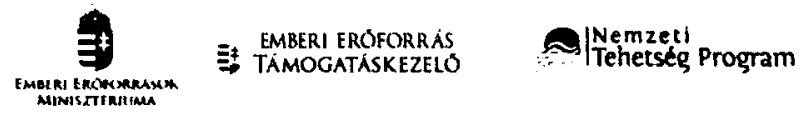

\section{Irodalomjegyzék}

Fabulya Z., Hampel Gy. (2016):_Biztonság és minöség konzervek hökezelési folyamatának szabályozásával. Jelenkori Társadalmi És Gazdasági Folyamatok, 10 (1): 119-126.

Gál J. (2008): Food Safety and Quality in Logistics Process in People's View: Az élelmiszerbiztonság és minöség a logisztikai folyamatban az emberek megítélése alapján, In: The 3rd International Scientific Conference, Safety and Quality of Raw Materials and Foodstuffs. Nyitra, Szlovákia, 2008.01.31.-2008.02.01. 157-160.

Hampel Gy. (2016): Transportation Habits of Szeged City Residents, Rewiew of Faculty of Engineering Analecta Technica Szegedinensia 10 (2): 69-78.

Huzsvai L., Vincze Sz. (2012): SPSS-könyv. Debrecen, SENECA BOOKS Kiadó.

Jánosa A. (2007): Adatelemzés számítógéppel. Budapest, Perfekt Kiadó.

Kiss M., Szakály Z., Soós M., Kontor E. (2016): Az egészségtudatosság megjelenése a magyar lakosság táplálkozási szokásaiban korcsoportonként, In: Bíró L., Gelencsér É., Lugasi A., Rurik I. (szerk.) A 60 éves Magyar Táplálkozástudományi Társaság XLJ. vándorgyülése: Program és az elóadások kivonatai, Esztergom, Magyarország, 2016.10.06.-2016.10.08. Budapest: Magyar Táplálkozástudományi Társaság, 38.

Kiss M., (2017): Az élelmiszer-vásárlói és -fogyasztói magatartás jellemzői, In: Szakály Z. (szerk.), Élelmiszer-marketing, Budapest, Akadémiai Kiadó. 518.

Kontor E., Szakály Z., Soós M., Kiss M., (2016): Egészségtudatos magatartás a 14-25 év közötti fiatalok körében, In: Fehér A., Kiss V. Á., Soós M., Szakály Z. (szerk.), EMOK XXII. Országos konferencia 2016 Tanulmänykötet: Hitelesség és értékorientáció a marketingben, 765. Konferencia helye, ideje: Debrecen, Magyarország, 2016.08.29.-2016.08.31. Debreceni Egyetem Gazdaságtudományi Kar.

Lehota J. (2001): Marketingkutatés az agrárgazdaságban. Budapest, Mezőgazdasági Kiadó.

Lehota J. (2006): Az élelmiszerfogyasztással kapcsolatos észlelt kockázatok és kockázatkezelési alternatívák, Élelmiszer, táplálkozás és marketing, 3 (1).

Malhotra N. K. (2008): Marketingkutatás, Akadémiai Kiadó, Budapest.

Nábrádi Zs., Kovács S., Szakály Z. (2017): Húsfogyasztási szokások összefüggése az evési attitüdökkel a fiatal felnőtt korosztályban, Marketing és menedzsment, 51 (emok különszám): 75-84.

Sajtos L., Mitev A. (2007): SPSS kutatási és adatkezelési kézikönyv. Budapest, Alinea Kiadó.

Scalera, F., Dumitrescu, C., Talpová, Sz. (2012): International crisis and competitiveness of service companies and public administration in Italy and in Europe: the application of lean office, Business and Management Review 2 (1): 63-75.

Soós M. (2017): A helyi (lokális) élelmiszer-marketing összefüggésrendszere, In: Szakály Z. (szerk.) Elelmiszer-marketing, Akadémiai Kiadó, Budapest.

Szakály Z. (2011): Táplálkozásmarketing, Mezőgazda Kiadó, Budapest. 
Szakály Z., Polereczki Zs., Jasák H., Fehér A., Soós M. (2014): A fogyasztók egészség magatartása: 500 fös Országos reprezentatív kérdöíves lakossági felmérés.

Szakály Z. (2017): Élelmiszer-marketing, Akadémiai Kiado, Budapest.

Tisca, I. A, Cornu, G., Diaconu, N., Dumitrescu, C. D. (2015): Diagnosis, risk and efficiency in the implementation of TQM in small and medium enterprises. Procedia Economics and Finance, (26): 215-218. 